\title{
Application of an association of yeast and lactic acid bacteria to bioencapsulate carotenoids in Daphnia magna (Straus, 1820)
}

\author{
Liliia Vasina, Ivanna Kraievska, Oleksii Khudyi, Lidiia Khuda, Larysa Cheban
}

Received - 07 October 2019/Accepted - 14 December 2020. Published online: 31 December 2020; $\odot$ Inland Fisheries Institute in Olsztyn, Poland Citation: Vasina L,, Kraievska I., Khudyi O., Khuda L., Cheban L. 2020 - Application of an association of yeast and lactic acid bacteria to bioencapsulate carotenoids in Daphnia magna (Straus, 1820) - Fish. Aquat. Life 28: 225-233

\begin{abstract}
Freshwater zooplankton, which is commonly used as a starting fish feed, has a low content of essential compounds such as carotenoids. The possibility of increasing the productivity of carotenogenic yeast, Rhodotorula glutinis, for further bioencapsulation of zooplankton Daphnia magna is shown. An association of a UV irradiated yeast strain with lactic acid bacteria was cultivated for this purpose. This permitted intensifying the carotenogenesis of yeast, and the content of $\beta$-carotene increased by 1.7 times, and that of torularodine by 2.3 times compared with the native monoculture. The use of the association of microorganisms as a feed substrate in the cultivation of Daphnia magna provided both an increase in the carotenoid content in the investigated crustaceans more than 8 times, and their biomass by 2.5 times compared with the standard feed of Saccharomyces cerevisiae.
\end{abstract}

Keywords: enriched live feed, essential compounds, lactic acid bacteria, Rhodotorula glutinis, zooplankton

\section{Introduction}

The pigmentation of hydrobionts is one of the decisive factors regulating their price in the commercial market for decorative and edible species.

L. Vasina [ ఏ], I. Kraievska, O. Khudyi, L. Khuda, L. Cheban Department of Biochemistry and Biotechnology, Yuriy Fedkovych Chernivtsi National University, Kotsubinsky Street 2, Chernivtsi, 58012, Ukraine

e-mail: l.vasina@chnu.edu.ua
Carotenoids are integral components of fish chromatophores and xanthophores, as well as dominant pigments of muscles and sex products of some species, and give a yellow to red color (Gupta et al. 2007). These compounds can also exist in binding states with proteins, forming carotenoproteins that have violet, green, or blue coloration (Shawkey and D’Alba 2017). In addition, pigments are precursors of vitamin $\mathrm{A}$, which is a necessary component in fish diets. These pigments are part of the antioxidant protection system (for example, astaxanthin exhibits high inhibitory activity against singlet oxygen, which is up to almost 100 times the index of $\alpha$-tocopherol, a standard antioxidant in plants and animals) (Shimidzu et al. 1996, de Carvalho and Caramujo 2017). Supplementing diets with carotenoids is shown to positively affect fish survival and growth. At the same time, it also improves specific and non-specific immunity and increases resistance to osmotic and temperature stress (Goda et al. 2018).

Since animals cannot synthesize carotenoids in their bodies de novo, supplementing diets with these pigments from other sources is required. Daphnia is used widely in aquaculture as live feed for fishes, and it can be used as an effective vector for the delivery of biologically active substances. This is confirmed by numerous studies on the enrichment of the nutritional content of Daphnia with essential substances 
and their bioencapsulation by prophylactic and therapeutic agents, etc., which has positive effects on fish survival and growth rates (Jafaryan et al. 2008, Gholomi 2010, Putra et al. 2016).

In biotechnology, algae (Cheban et al. 2018) or yeasts (Tuchapska and Krazhan 2014) are used as feed substrates for the cultivation of zooplankton, taking into account their rich intracellular composition and the presence of easily digestible proteins, carbohydrates, and vitamins. Carotenogenic yeast, Rhodotorula glutinis, can be a source of carotenoids with which zooplankton can be enriched (Kushniryk et al. 2014). In this case, the quantitative and qualitative content of pigments in yeast cells can be corrected by exposure to ultraviolet irradiation, as well as by joint cultivation with symbiotic microorganisms, for example, lactic acid bacteria, which permit using inexpensive cultivation media.

It follows from the foregoing, the purpose of our work was to study the accumulation of certain nutrients in zooplankton biomass by applying bioencapsulation technology with pigmented yeast after increasing its carotenogenic activity.

\section{Materials and Methods}

The research was conducted on a native monoculture of the yeast, Rhodotorula glutinis, strain UCM Y-1242. A culture of lactic acid bacteria was isolated from the mucous membranes of the digestive tract of sturgeon. The monoculture of cladocerans, Daphnia magna (Straus), was obtained from the collection of the Institute of Biology, Chemistry, and Bioresources of the Yuri Fedkovich Chernivtsi National University.

\section{Ultraviolet irradiation of yeasts}

To increase the carotenoid synthesis ability, Rhodotorula glutinis was irradiated with ultraviolet radiation at $\lambda=254 \mathrm{~nm}$, as described previously (Kraievska and Vasina 2017). The selection of colonies was carried out for the intensity of their coloring.

\section{Co-cultivation of microorganisms}

To increase biomass growth, cultivation was conducted with lactic acid bacteria using a modified medium based on milk whey (Frengova et al. 2004). The inoculum of yeast was cultivated for 48 hours in the liquid Sabouraud medium, while the inoculum of lactic acid bacteria was cultivated for 24 hours in the medium with milk whey. Subsequently, the number of microorganisms was concentrated, planted in the medium (inoculum of yeast - 10\%, inoculum of microorganic bacteria - 5\%), and conventional fermentation was conducted in an Erlenmeyer flask for 5 days at a temperature of $28^{\circ} \mathrm{C}$ on an electric shaker LAB-PU-01 (160 rpm (rotations per minute)).The dynamics of biomass accumulation of yeast was evaluated by measuring the optic density of the suspension on a spectrophotometer at $\lambda=625 \mathrm{~nm}$. In co-cultivation of yeast and lactic acid bacteria, the number of yeast cells was determined with the technique of counting colony-forming units.

\section{Cultivation of zooplankton}

Freshwater zooplankton was cultivated in a modified ADAM medium (Kluttgen et al. 1994) in $500 \mathrm{ml}$ containers at an initial density of 50 ind. $\times 1^{-1}$. During growth, a 16-hour photoperiod and a temperature of $22 \pm 2^{\circ} \mathrm{C}$ were maintained in the climatic room. To use the association of carotenogenic yeast, $R$. glutinis, and lactic acid bacteria as a feed substrate, the culture was separated from the nutrient medium and washed with distilled water by centrifugation for 20 minutes at $3000 \mathrm{rpm}$. The suspension of microorganisms obtained was standardized by the number of yeast $24 \times 10^{6}$ cells $\mathrm{L}^{-1}$ of distilled water. As a control feed substrate for zooplankton, an aqueous suspension of Saccharomyces cerevisiae yeast was standardized with the number of cells $24 \times 10^{6}$ cells $\mathrm{L}^{-1}$ of of distilled water. The addition of the yeast suspension as well as biomass associated microorganisms was performed every 48 hours for 4 days in the amount of $0.5 \mathrm{~g} \times \mathrm{L}^{-1}$ (Kushniryk et al. 2015b). 


\section{Biochemical assays}

Biochemical analyzes were conducted in the phase of greatest productivity. The concentrated yeast biomass was hydrolyzed with $1 \mathrm{~N} \mathrm{HCl}$ in a boiling water bath for 10 minutes and centrifuged for $10 \mathrm{~min}$ at $3000 \mathrm{rpm}$ to obtain sediment, which was followed by further manipulations. The zooplankton biomass was treated with a USDN-2T ultrasonic disintegrator. These samples were used for further research. Determinations of carotenoid content were performed after acetone extraction with the spectrophotometric method at appropriate wavelengths for the expected pigments (Finkel'shtein 2016). The total protein content was determined with the Lowry method (Lowry et al. 1951). Lipid extraction was performed using the Blay-Dyer method (Bligh and Dyer 1959). The resulting extract was reacted with a phosphate-vanillin reagent (Knight 1972). To calculate the dry weight, samples were dried at $60^{\circ} \mathrm{C}$ for 24 hours until a constant mass was obtained.

\section{Statistical analysis}

All the data are presented as mean \pm SEM. The number of replications was $6(n=6)$ for each microbiological and biochemical parameter. All the results of the experiments were analyzed with one-way analysis of variance (ANOVA), followed by Tukey's or Student's post hoc test to determine significant differences. Mean values were considered significantly different at $\mathrm{p} \leq 0.05$. The statistical analysis was performed using MS Excel and STATISTICA 10.0.

\section{Results}

Spectrophotometric measurements permitted recording changes in the concentration of three major carotenoid fractions in the irradiated yeast cells. The largest number, like in the native culture, was $\beta$-carotene. Its content in yeast cells after irradiation increased 1.3 times and amounted to $52 \%$ of the total carotenoids. In addition, there was a significant increase in the content of torularodine (1.7 times compared to the native culture). The irradiated $R$. glutinis formed small amounts of torulin.

Carotenogenesis in R. glutinis cells intensified when they were cultivated in association with lactic acid bacteria, and both natural and irradiated yeasts showed this effect. The tendency discovered previously was preserved; the amount of carotenoids in the cells of the modified culture remained higher than in the native culture. The following changes in the number of individual carotenoid fractions were registered in the native culture: the content of $\beta$-carotene increased by $28 \%$ and torulin by 1.6 times, while torularodine remained unchanged.

In the irradiated culture, the following regularities were found: the level of $\beta$-carotene and torularodine increased by 1.4 times and that of torulin by approximately 3 times. The most evident differences were those in the ratios of individual carotenoid fractions when evaluating the "extreme" research groups - the native culture of $R$. glutinis, grown in the traditional Sabouraud medium and the irradiated culture under co-cultivation conditions: the content of $\beta$-carotene varied 1.7 times, while torularodine did so 2.3 times (Fig. 1).

However, along with the positive trend regarding the number of photoprotective pigments in irradiated yeast cells, we recorded a 1.5-fold decrease in the accumulation of the biomass of these microorganisms. When we cultivated the irradiated yeast in association with lactic acid bacteria, we recorded an increase in the number of live yeast cells at the end of the basic fermentation by an average of 35\% compared to the cultivation of the irradiated monoculture (Fig. 2).

The association of irradiated $R$. glutinis and lactic acid bacteria, which was characterized by high carotenogenic ability, was used to bioencapsulate $D$. magna zooplankton. During the period of maximum accumulation of biomass, the content of total carotenoids in all experimental groups was increased compared to the control group, which was fed with $S$. cerevisiae. For instance, in the group that was fed 


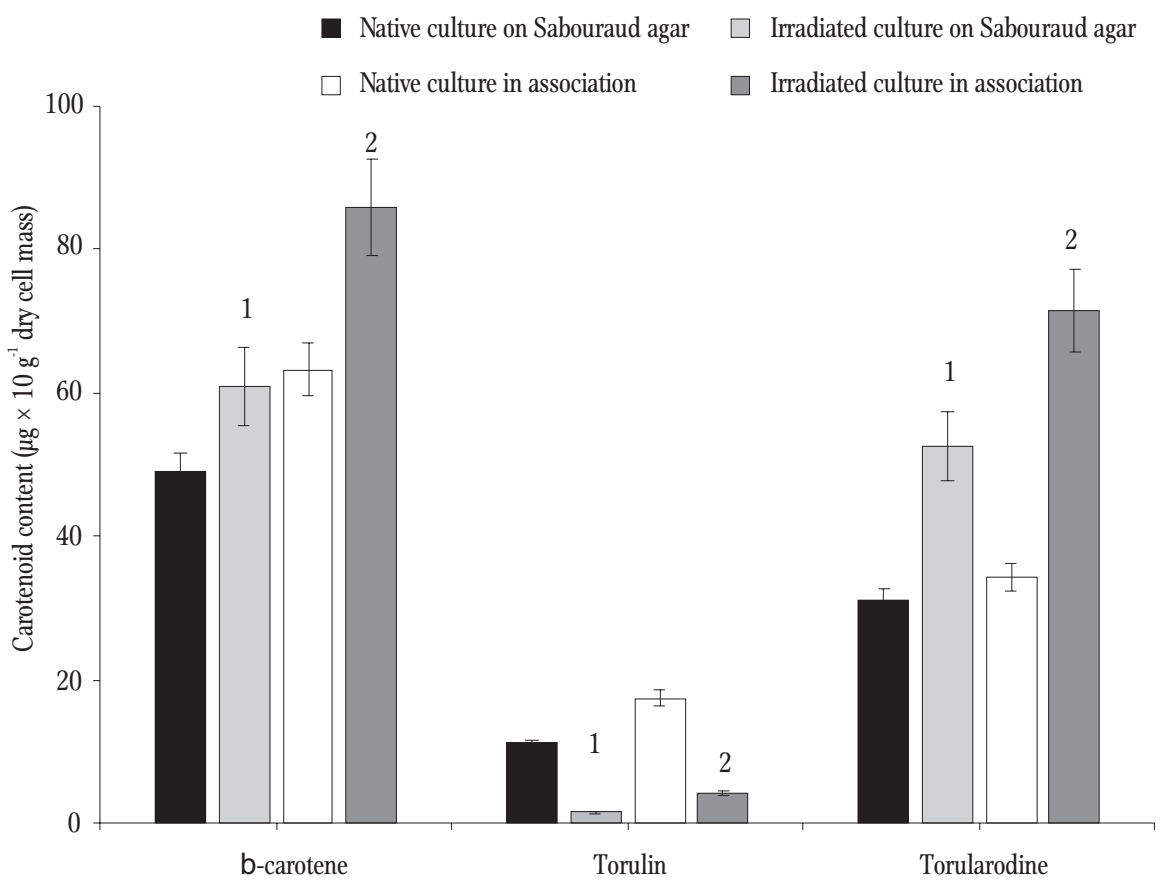

Figure 1. Content of individual carotenoid fractions in $R$. glutinis monoculture or in association with lactic acid bacteria before and after irradiation. Note: 1 - differences between groups of native and irradiated cultures of $R$. glutinis were statistically significant (P $\leq .05) ; 2-$ differences between groups of native and irradiated cultures of $R$. glutinis in association were statistically significant $(\mathrm{P} \leq 0.05)$.

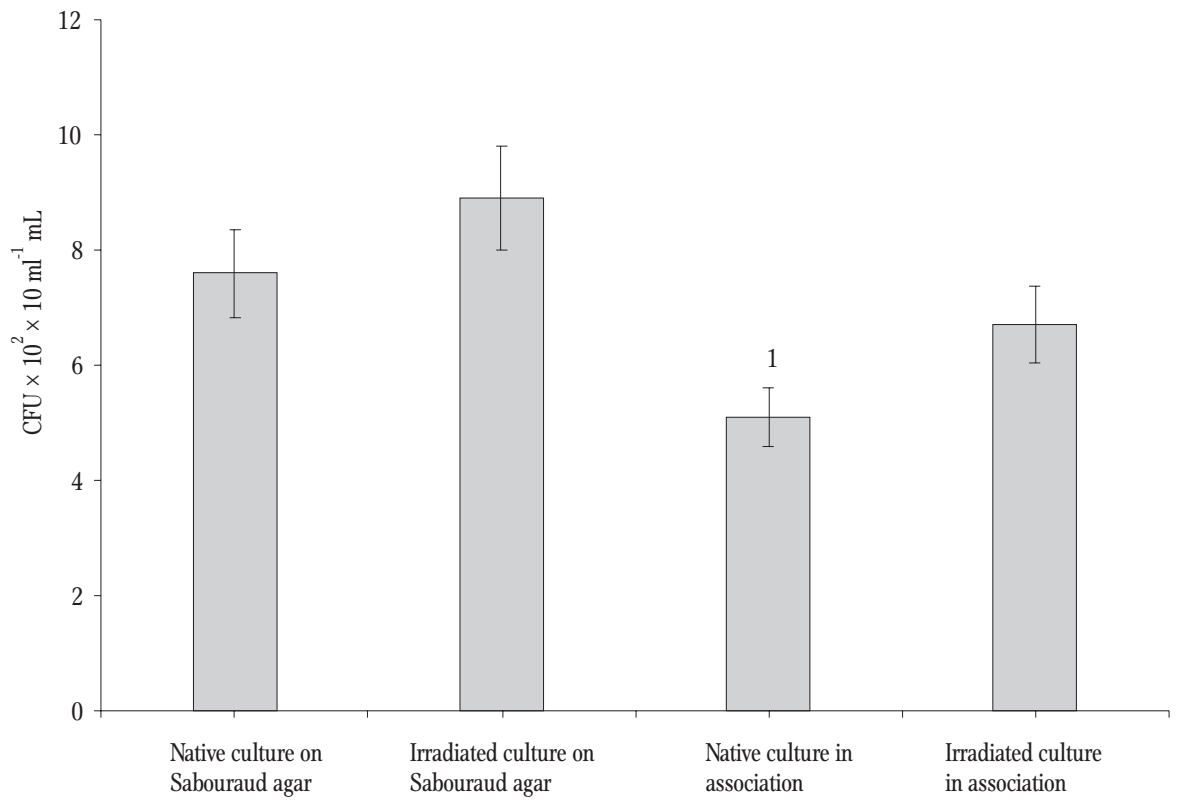

Figure 2. Number of native or irradiated $R$. glutinis colonies on Sabouraud agar medium after 120 hours of basic fermentation in liquid media in monoculture or in association with lactic acid bacteria. Note: 1 - differences between groups of native and irradiated cultures of R. glutinis were statistically significant $(\mathrm{P} \leq 0.05)$

with the native culture of $R$. glutinis this number increased 4.8 times, but the increase was 7 times in the group fed the irradiated culture, and more than 8 times in the groups fed the association of microorganisms. (Fig. 3).
The analysis of the biochemical composition of D. magna fed with carotene-containing yeast showed some increase in total protein content. The highest values were registered in zooplankton fed the association of microorganisms (Fig. 4). The evaluation of 


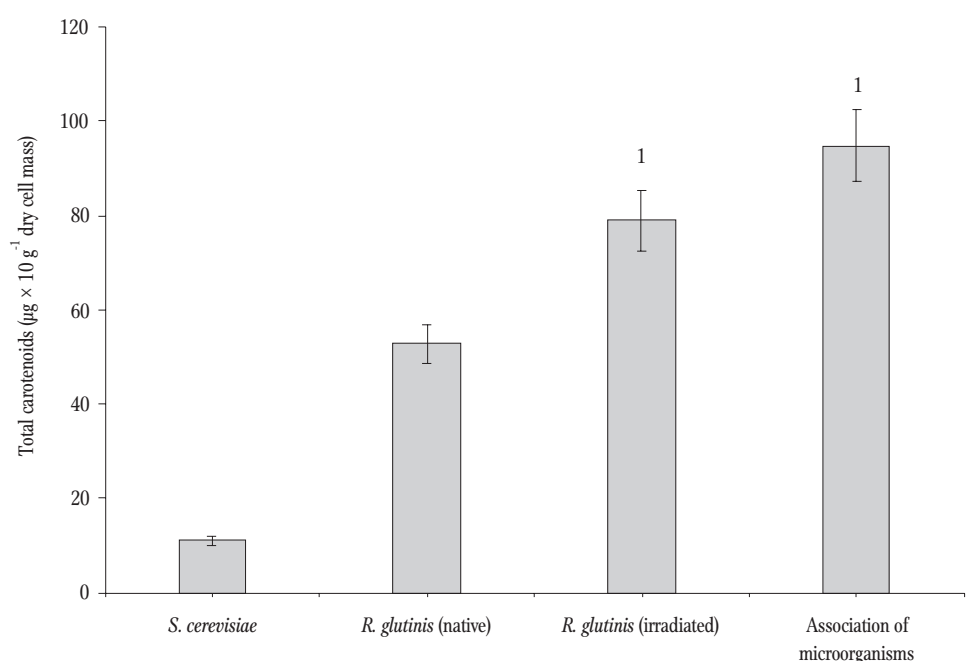

Figure 3. Content of total carotenoids in D. magna biomass with the application of different nutrient substrates. Note: 1 - differences between groups of native and irradiated cultures of $R$. glutinis were statistically significant $(\mathrm{P} \leq 0.05)$
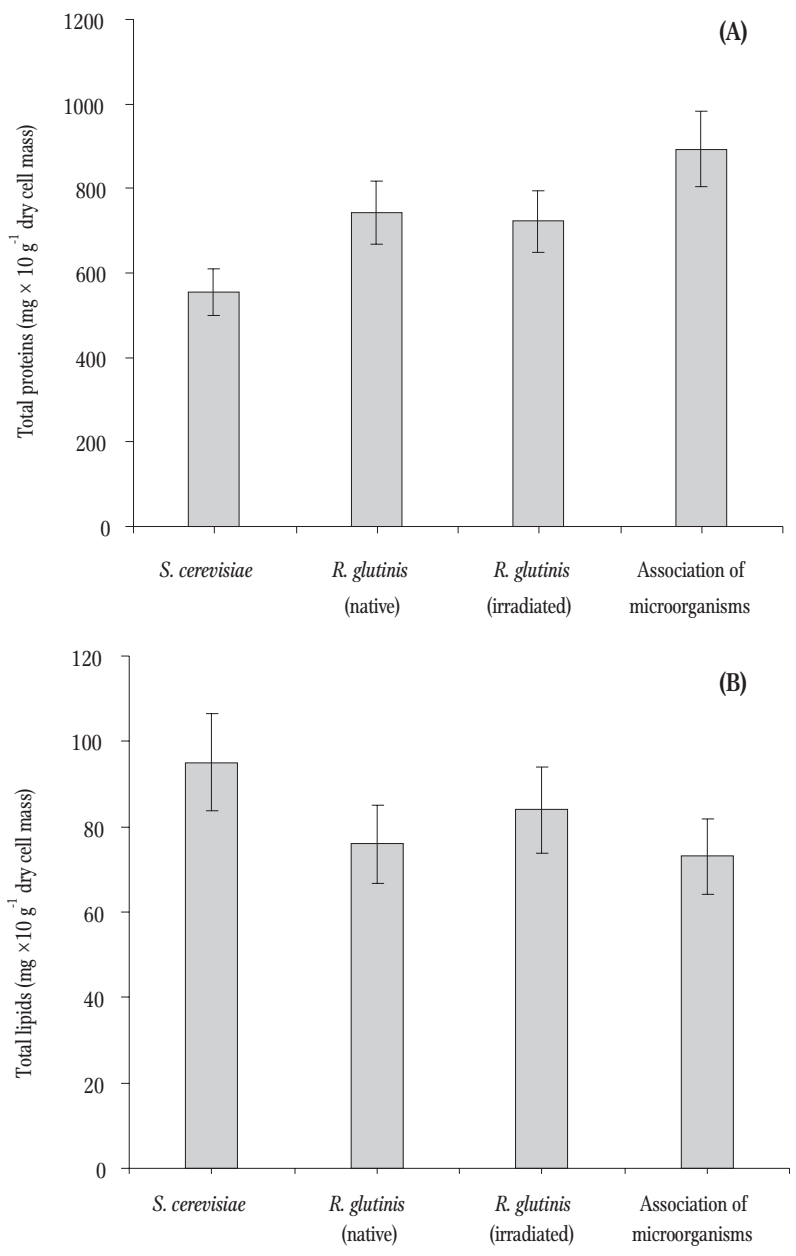

Figure 4. Content of total proteins (A) and lipids (B) in D. magna biomass in which different nutrient substrates. total lipid content in all experimental groups showed insignificant variability.

It was also established that using carotenogenic yeast as a substrate for $D$. magna intensified the growth of zooplankton biomass. The highest density of culture was registered with the use of the association of microorganisms - it increased 2.5 times compared with the standard feed substrate S. cerevisiae (Fig. 5).

\section{Discussion}

Live feed is better assimilated by early fish developmental stages, and compared to artificial feeds, it has a positive effect on survival and growth rates (Das et al. 2012). Daphnia is one of the most common feeds for fish larvae. This type of zooplankton has a high nutritional value and contains about $70 \%$ proteins and 27\% lipids (Kibria et al. 1997). Daphnia has a wide range of enzymes, including proteases, peptidases, amylase, lipase and even cellulases, which serve as an additional source for fish larvae that are not yet fully capable of synthesizing them (Malla and Banik 2015). Small crustaceans are able to accumulate and transform carotenoids that are essential for the development of fish (Weaver et al. 2018). Carotenogenic yeast, $R$. glutinis, which is used for bioencapsulation, is similar in its biochemical composition to the standard substrate for the cultivation of zooplankton Saccharomyces cerevisiae. They have the following chemical composition: proteins $-47.5-49 \%$, carbohydrates - 33-35\%, lipids - 3.5-3.8\%, minerals $10 \%$, and they contain pro-vitamin D, thiamine, riboflavin, pyridoxine, cyanocobalamin, pantotehenum, nicotinic, folium, and ascorbic acid (Bertolo et al. 2019). According to literature data, the use of carotenogenic yeast of the genus Rhodotorula as a feed substrate allows for the maximum increase of carotenoids in the live feed of M. macrocopa and $S$. vetulus as early as by the fourth day of cultivation (Kushniryk et al. 2015a, 2015b). 


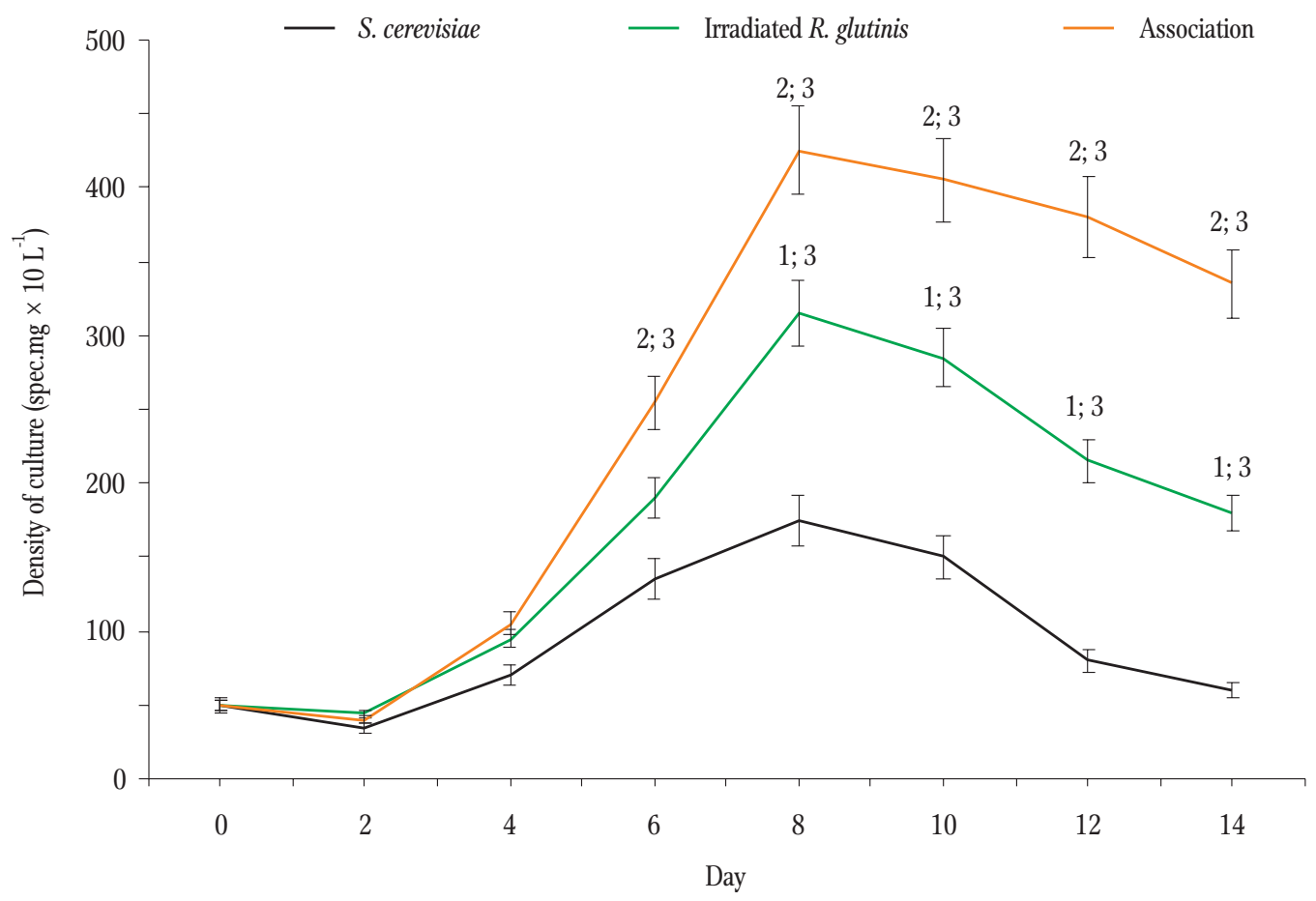

Figure 5. Dynamics of culture density when different nutrient substrates were applied. Note: 1 - differences between groups of $D$. magna in which $S$. cerevisiae and the irradiated culture of $R$. glutinis were applied were statistically significant $(\mathrm{P} \leq 0.05)$; $2-$ differences between groups of $D$. magna in which $S$. cerevisiae and irradiated cultures of $R$. glutinis in association were applied were statistically significant ( $\mathrm{P} \leq 0.05)$; 3 - differences between groups of D. magna in which irradiated cultures of $R$. glutinis and irradiated cultures of $R$. glutinis in association were applied were statistically significant $(\mathrm{P} \leq 0.05)$

Carotenoids in yeast cells act as photoprotectors; therefore, elevated doses of ultraviolet light, which induce the formation of protective compounds, are used as a method for the directional synthesis of pigments (Frengova and Beshkova 2009). UV-B or UV-C are used as a mutagenic factor (Brosale and Gadre 2001, Moliné et al. 2010). The action of ultraviolet radiation with a wavelength of $254 \mathrm{~nm}$ leads to a redistribution of carotenoid content, with the increase of the content of the specific pigment torularodine (Kraievska and Vasina 2017). This effect can be explained by the connotations of carotinoid metabolism. As is known, torularodine is a pigment with high antioxidant potential and a powerful absorbent of singlet oxygen and peroxide radicals. In this case, it inhibits peroxides more effectively than $\beta$-carotene and $\alpha$-tocopherol (Moliné et al. 2010).

It is highly probable that the accumulation of this carotenoid is the response of the yeast cells to the oxidative stress caused by the action of UV-agents.
Along with the positive trend regarding the number of photoprotective pigments in irradiated yeast cells, we recorded a decrease in the accumulation of biomass, probably due to the negative effect of UV from the oxidative degradation of biopolymers associated with both the direct action of radiation and the indirect action from the formation of free radicals (Rastogi et al. 2010).

The low growth rate of biomass by these microorganisms called for the development of methods to increase the growth of the culture studied. The accumulation of biomass depends to a large extent on the presence of organogenic elements in the medium and their availability for microbiological dismultiration. According to the literature, growing yeast on the medium with milk whey as part of an association with lactic acid bacteria positively affects carotene synthesizing properties and increases biomass productivity. Lactic acid bacteria contain the enzyme $\beta$-galactosidase, which actively transforms lactose into galactose and glucose, from which, in 
turn, lactic acid is formed (Frengova et al. 2003). These substances are available substrates for yeasts. On the other hand, the importance of forming an association of these microorganisms was justified by the probiotic properties of lactic acid bacteria. Probiotics not only exhibit antagonistic effects on pathogenic microorganisms, but they also have positive effects on the healing of ulcers, the normalization of mucus formation on the surface of fish bodies, the improvement of the gill apparatus, the stabilization of intestinal functions, the enhancement of enzymatic activity, and the activation of specific and nonspecific macroorganism immune systems (Balcázar et al. 2008).

The results of the present research showed that the use of the association of irradiated culture of $R$. glutinis and lactic acid bacteria as a nutrient substrate for zooplankton led to the active accumulation of D. magna carotenoids, which exceeded values for yeast monocultures. For these crustaceans, and for other cladocerans, bioconversion occurs prior to the deposition of carotenoids in tissues. For example, in a diet with a high $\beta$-carotene content, keto- and hydroxy-derivatives are mainly accumulated in the body - astaxanthin, cantaxanthin, echinenon, and others. In this case, oxygen-containing carotenoids form the bulk of other pigments in the muscles, genitals, and eggs of many fish species, which proves their decisive role in the ontogenesis of hydrobionts (Shahidi and Brown 1998).

It was assumed that the active accumulation of zooplankton carotenoids could lead to the redistribution of the ratio of individual nutrients and reduce the nutritional value of the plankton. The present research established that the consumption of an association of microorganisms by zooplankton not only did not lead to decreases in basic nutrients, but it also partially increased protein quantity. For aquatic animals, protein is an essential nutrient for growth, the synthesis of hormones and enzymes, and the formation of the respiratory and reproductive systems. Young fish are more susceptible to protein deficiency than adults (Manklinniam et al. 2018). The nutritional value of zooplankton for early developmental stage fishes is determined not only by the high content of proteins in the living feed, but also by the fact that $50-70 \%$ of the protein is in soluble form, with a large part of it being presented as products of protein metabolism, i.e., peptides with low molecular weights and free amino acids (Bogut et al. 2010).

The lactic acid bacteria probably played a role in the enrichment of zooplankton with valuable nutrients. The amino acid composition of the bacterial protein is complete (Simova et al. 2006), and a wide range of hydrolytic enzymes contributes to the digestive process and the prevention of contamination.

\section{Conclusions}

This study demonstrated the possibility of co-cultivating carotenogenic yeast and lactic acid bacteria in a medium with milk whey. This led to an increase in the accumulation of biomass and to the increased carotenogenic activity of Rhodotorula glutinis. This association of microorganisms can be used in bioencapsulation technology for live feed. At the same time, the biomass of Daphnia magna increased the content of total carotenoids and did not disturb the balance of individual nutrients as the nutritional value of the zooplankton increased.

Author contributions. L.V., I.K., and O.K. designed the research. I.K. performed the research and statistical analysis. L.K. and L.C. were responsible for the bioencapsulation technology. All of the authors were involved in formulating the results, drafting the manuscript, and they all approved the final manuscript.

ORCID ID

Liliia Vasina iD https://orcid.org/0000-0001-5458-3537

Oleksii Khudyi (iD https://orcid.org/0000-0001-5652-0900

Lidiia Khuda (D) https://orcid.org/0000-0002-1098-7537

Larysa Cheban (iD https://orcid.org/0000-0003-1454-0158

\section{References}

Balcázar J. L., Vendrell D., de Blas I., Ruiz-Zarzuela I., Muzquiz J. L., Girones O. 2008 - Characterization of probiotic properties of lactic acid bacteria isolated from 
intestinal microbiota of fish - Aquaculture 278: 188-191.

Bertolo A.P., Biz A.P., Kempka A.P. Rigo E., Cavalheiroet D. 2019 - Yeast (Saccharomyces cerevisiae): evaluation of cellular disruption processes, chemical composition, functional properties and digestibility - J. Food Sci. Technol. 56: 3697-3706.

Bligh E.G., Dyer W.J. 1959 - A rapid method of total lipid extraction and purification - Can. J. Biochem. Physiol. 37: 911-917.

Bogut I., Adamek Z., Puškadija Z. 2010 - Nutritional value of planktonic cladoceran Daphnia magna for common carp (Cyprinus carpio) fry feeding - Ribarstvo 68: 1-10.

Brosale P., Gadre R. 2001 - Production of $\beta$-carotene by a mutant of Rhodotorula glutinis - Appl. Biochem. Biotechnol. 55: 423-427

de Carvalho C.C.C.R., Caramujo M.J. 2017 - Carotenoids in aquatic ecosystems and aquaculture: a colorful business with implications for human health - Front. Mar. Sci. 4: 93.

Cheban L., Grynko O., Dorosh I. 2018 - Co-cultivation of Daphnia magna (Straus) and Desmodesmus armatus (chod.) Hegew. in recirculating aquaculture system wastewater - Fish. Aquat. Life 26: 57-64.

Das P., Mandal S.C., Bhagabati S.K., Akhtar M.S., Singh S.K. 2012 - Important live food organisms and their role in aquaculture - In: Frontiers in Aquaculture (Eds) J.K. Sundaray, M. Sukham, R.K. Mohanty, S.K. Otta, Narendra Publishing House, India, New Delhi: 69-86.

Finkel'shtein E.I. 2016 - Modern Methods of Analysis of Carotenoids (Review) - Pharm. Chem. J. 50: 96-107.

Frengova G.I., Beshkova D.M. 2009 - Carotenoids from Rhodotorula and Phaffia: yeasts of biotechnological importance - J. Ind. Microbiol. Biotechnol. 36: 163-180.

Frengova G.I., Emilina S.D., Beshkova D.M. 2003 Carotenoid production by lactoso-negative yeasts co-cultivated with lactic acid bacteria in whey ultrafiltrate - Z. Naturforsch C 58: 562-567.

Frengova G.I., Simova E.D., Beshkova D.M. 2004 - Use of whey ultrafiltrate as a substrate for production of carotenoids by the yeast Rhodotorula rubra - Appl. Biochem. Biotechnol. 112: 133-141.

Gholomi M. 2010 - Effect of n-3 HUFA enriched Daphnia magna on growth, survival, stress resistance and fatty acid composition of white fish fry (Rutilus frisii kutum) J. Fish. Aquac. Sci. 5: 49-55.

Goda A.A., Sallam A. E., Srour T. M. 2018 - Evaluation of natural and synthetic carotenoid supplementation on growth, survival, total carotenoid content, fatty acids profile and stress resistance of European seabass, Dicentrarchus labrax, fry - Aquac. Stud. 18: 27-39.

Gupta S.K., Jha A.K., Pal A.K., Venkateshwarlu G. 2007 Use of natural carotenoids for pigmentation in fishes Nat Prod. Radiance 6: 46-49.
Jafaryan H., Morovat R., Shirzad H. 2008 - The use of bioencapsulated Daphnia magna by probiotic bacillus and their effect on the growth of Rainbow trout (Oncorhynchus mykiss) larvae - Iranian J. Biol. 21: 24-35.

Kibria G., Nugegoda D., Fairclough R., Lam P., Bradly A. 1997 - Zooplankton: its biochemistry and significance in aquaculture - NAGA. ICLARM Q. 20: 8-12.

Kluttgen B., Dulmer U., Engels M., Ratte H.T. 1994 - ADaM, an artificial fresh water for the culture of zooplankton Water Res. 28: 743-746.

Knight J.A., Anderson S., Rawle J.M. 1972 - Chemical basis of the sulfo-phospho-vanillin reaction for estimating total serum lipid - Clin. Chem. 18: 199-202.

Kraievska I.M., Vasina L.M. 2017 - Dynamics of biomass accumulation and carotene synthesizing activity of Rhodotorula glutinis (Fresenius) F.C. Harrison (1982) under the action of ultraviolet radiation - Biolgical Systems 9: 183-186 (in Ukrainian)

Kushniryk O.V., Marchenko M.M., Khudyi O.I., Vasina L.M., Khuda L.V., Kavulya O.M. 2014 - The application of yeast Rhodotorula glutinis for cultivation of Simocephalus vetulus (Müller, 1776) under the laboratory conditions - Biolgical Systems 6: 24-29 (in Ukrainian).

Kushniryk O.V., Khudyi O.I., Khuda L.V. 2015a - Hydrolytic activity and nutritional value of Simocephalus vetulus (Muller) during cultivation with different feeding substrates - Odesa National University Herald. Biology. 20: 115-120 (in Ukrainian).

Kushniryk O., Khudyi O., Khuda L., Kolman R., Marchenko M. 2015b - Cultivating Moina macrocopa Straus in different media using carotenogenic yeast Rhodotorula Arch. Pol. Fish. 23: 37-42.

Lowry O.H., Rosebrough N.J., Farr A.L., Randall R.J. 1951 Protein measurement with the Folin phenol reagent - J. Biol. Chem. 193: 265-275.

Malla S., Banik S.K. 2015 - Production and application of live food organisms for freshwater ornamental fish larviculture - Adv. Biores. 6: 159-167.

Manklinniam P., Chittapun S., Maiphae S. 2018 - Growth and nutritional value of Moina macrocopa (Straus, 1820) fed with Saccharomyces cerevisiae and Phaffia rhodozyma - Crustaceana 91: 897-912.

Moliné M., Flores M.R., Libkind D., del Carmen Diéguez M., Farías M.E., van Broock M. 2010 - Photoprotection by carotenoid pigments in the yeast Rhodotorula mucilaginosa: the role of torularhodin - Photochem. Photobiol. Sci. 9: 1145-1151.

Putra D.F., Fanni, M., Muchlisin Z.A., Muhammadar A.A. 2016 - Growth performance and survival rate of climbing perch (Anabas testudineus) fed Daphnia sp. enriched with manure, coconut dregs flour and soybean meal AACL Bioflux 9: 944-948. 
Rastogi R.P., Richa Kumar A., Tyagi M.B., Sinha R.P. 2010 Molecular mechanisms of ultraviolet radiation-induced DNA damage and repair - J. Nucleic Acids 2010: 592980.

Shahidi F., Brown J.A. 1998 - Carotenoid pigments in seafoods and aquaculture - Crit. Rev. Food Sci. 38: 1-67.

Shawkey M.D., D’Alba L. 2017 - Interactions between colour-producing mechanisms and their effects on the integumentary colour palette - Philos. Trans. R. Soc. B. Biol. Sci. 372: 20160536

Shimidzu N., Goto M., Miki W. 1996 - Carotenoids as singlet oxygen quenchers in marine organisms - Fish. Sci. 62: 134-137.
Simova E., Simov Z., Beshkova D., Frengova G., Dimitrov Z., Spasov Z. 2006 - Amino acid profiles of lactic acid bacteria, isolated from kefir grains and kefir starter made from them - Int. J. Food Microbiol. 107: 112-123.

Tuchapska A., Krazhan S. 2014 - Cultivation of cladoceran for increasing provision of young-of-the-year carp with natural feeds (review) - Fisheries Science of Ukraine 2: 55-68 (in Ukrainian)

Weaver R.J., Cobine P.A., Hill G.E. 2018 - On the bioconversion of dietary carotenoids to astaxanthin in the marine copepod, Tigriopus californicus - J. Plankton Res. 40: $142-150$. 